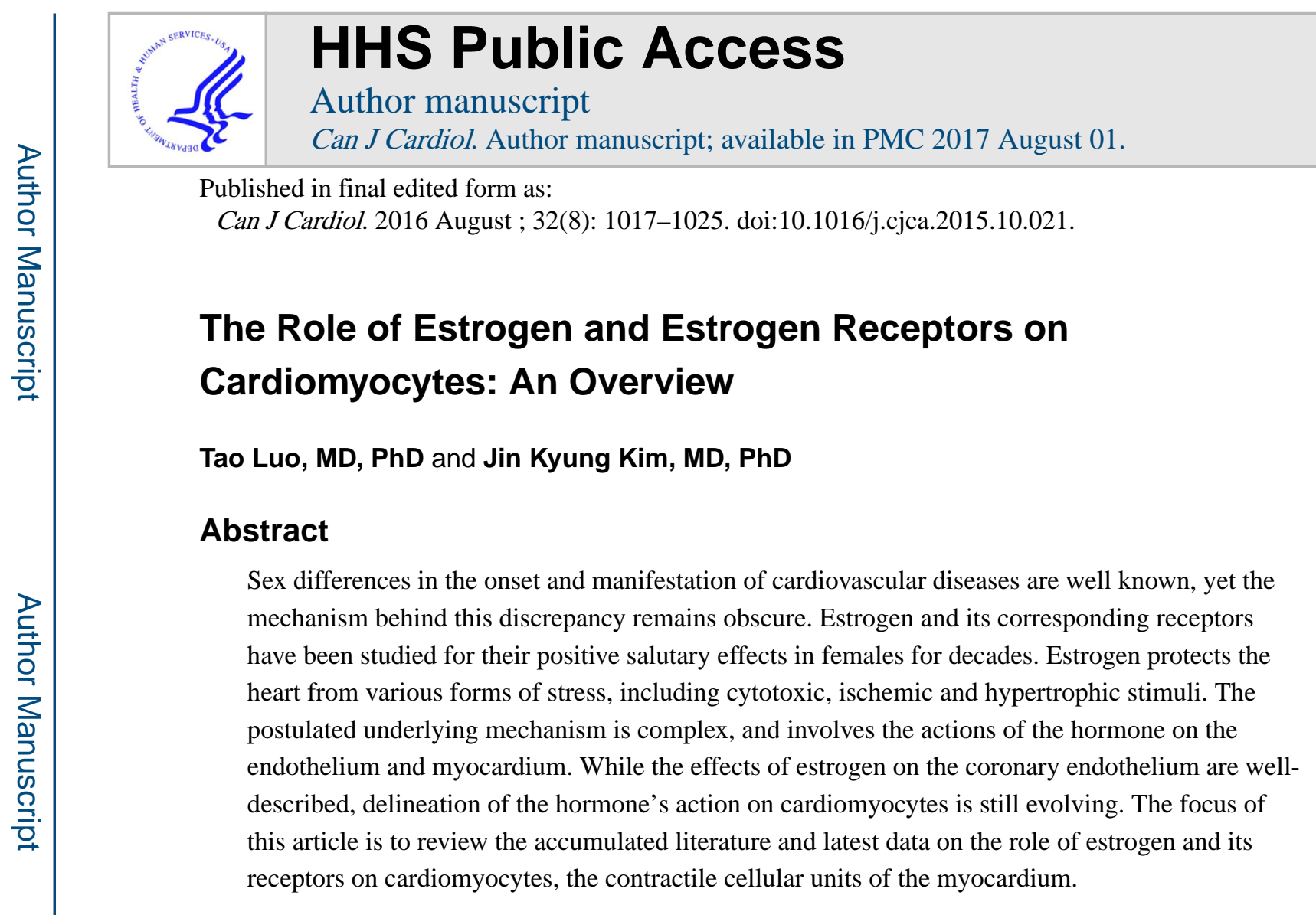

\title{
Introduction
}

Gender is increasingly recognized as a major factor in the outcomes of patients with cardiovascular diseases (CVD). Findings from clinical studies suggest that premenopausal women have reduced incidence of CVD, compared to age-matched men. This observation has led to the postulation that estrogen, working via its receptors, may be cardioprotective, the conclusion supported by numerous controlled experiments at preclinical levels. However, trials testing the role of hormone replacement therapy (HRT) as a preventive measure have yielded mixed results, ${ }^{1}$ with two such studies, Women's Health Initiative (WHI) ${ }^{2}$ and Heart and Estrogen/progestin Replacement Study (HERS), ${ }^{3}$ showing no substantial benefit overall. The discrepancy between the initial findings of these trials and the cardioprotection by estrogen seen in experimental models is a complex topic that has been covered extensively elsewhere and continues to be debated to this date. ${ }^{4}$ Briefly, it includes the issues of the study design and subject characteristics, pharmacokinetics of the HRT used, statistical power to address cardiac risk, composite analyses of all outcomes of different diseases rather than focusing on cardiac end points.

Subsequent analyses of these trial data, however, showed significant cardiovascular benefits in younger patients who initiated HRT early in the perimenopausal period, raising a question of the "timing hypothesis" and leaving room for further debate on the role of HRT in CVD. More recently, the timing hypothesis was specifically addressed by the Kronos Early

Corresponding Author: Jin Kyung Kim, Division of Cardiology, Department of Medicine, University of California Irvine Medical Center, Orange, CA 92868, USA, Phone: 949-824-1461, Fax: 949-824-1316, jkim13@uci.edu.

Disclosures: The authors have no conflicts of interest to disclose. 
Estrogen Prevention Study (KEEPS) and the Early versus Late Intervention Trial with Estradiol (ELITE). The KEEPS showed that HRT started early in menopause improved markers of CVD risk. ${ }^{5}$ Results of the ELITE are yet to be published, but preliminary reports provide evidence directly supporting the timing hypothesis. ${ }^{6,7}$ Thus, salutary relevance of HRT in CVD is far from being clearly defined, and remains a complex and controversial issue.

Cardiomyocytes and coronary endothelium are two principal units of the heart implicated in the pathophysiological processes underlying ischemic heart disease (IHD), a major component of CVD and the leading cause of death in developed countries. It is wellrecognized that estrogen has potent impact on the vascular endothelium and the heart. ${ }^{8}{ }^{8}$ In this review, we will examine the molecular, cellular, and physiological evidence of estrogen's action on cardiomyocytes, the cells making up the largest part of the heart by mass and chiefly responsible for cardiac contraction and conduction, in order to further understand the intricate effects of the female hormone on the heart and IHD.

\section{The source of estrogen}

Estrogens are a group of sex steroids that exerts pleiotropic actions on multiple organs beyond the scope of its reproductive function. The primary sources of estrogens in premenopausal females are the ovaries. Estrogens are also produced in a number of extragonadal sites, including bone, breast, adipose tissue and the brain. ${ }^{10}$ Estrogens can be converted from testosterone by cytochrome $\mathrm{p} 450$ aromatase in the testis and prostate in men. ${ }^{11,12}$

\section{Circulating estrogen}

Three naturally occurring estrogens in circulation are estrone (E1), 17ß-estradiol (E2) and estriol (E3). Of these, E2 is the most potent. The secretion of E2 is pulsatile and its concentration fluctuating within a menstrual cycle $(100-600 \mathrm{pg} / \mathrm{ml})$. It can rise up to 17000 $\mathrm{pg} / \mathrm{ml}$ during pregnancy. ${ }^{13}$ After menopause, serum E2 concentration precipitously drops to values similar to, or lower than, those in men of similar age $(5-20 \mathrm{pg} / \mathrm{ml}) .{ }^{14} \mathrm{E} 2$ is also the most commonly used bioactive estrogen in experiments, and for the remainder of this article, we will use E2 and estrogen interchangeably.

\section{Cardiac estrogen}

Local estrogen biosynthesis requires cytochrome P450 aromatase (CYP19A1), which metabolizes androstenedione and testosterone to their respective estrogens by aromatization. ${ }^{15}$ The enzyme activity of $\mathrm{P} 450$ aromatase was reported to be present in various extra-gonadal tissues more than two decades ago, and its transcript splicing shown to be tissue-specific, ${ }^{16}$ strongly suggesting an organ-dependent transcriptional regulation of the aromatase. There is now increasing evidence that the aromatase is expressed in the heart. ${ }^{17-19}$ These findings hint a local estrogen production in the heart. Given the relationship between sex hormones and aromatase expression in situ reported in other organs and association of aromatase polymorphism with CVD risk, these data provide functional 
implications about local E2 activity and cardiac aromatase in E2-mediated cardioprotection. ${ }^{20-22}$

\section{Cardiac estrogen receptors}

There are two classic nuclear estrogen receptors (ERs), ERa and ER $\beta$, encoded by ESR1 and ESR2, respectively. They are widely expressed in different tissue types, in addition to uterus and ovary. Both receptors are expressed in the adult and neonatal heart, ${ }^{23-25}$ and both in the ventricular and atrial cells from female and male mice. ${ }^{26}$ The cardiac ERs are functionally active, participating in the regulation of gene expression and posttranslational modifications through genomic and non-genomic signaling pathways. ${ }^{27}$ Evidence on the whole shows that ERs exert anti-apoptotic, pro-hypertrophic, anti-inflammatory, antiatherosclerotic, vasodilatory, and angiogenic effects in the cardiovascular system. ${ }^{27-30}$

The immunohistochemical analysis of the receptors indicates their subcellular localization to be distinct from each other. While both are seen in the cytosol of cardiac cells, the extent of nuclear localization is different between the two subtypes. ERa was found in the cardiomyocyte plasma membrane, while equivalent evidence for ER $\beta$ is lacking. ${ }^{26}$ Both receptor subtypes are found in the mitochondria of cardiomyocytes, and participate in the ER-initiated regulation of mitochondrial function. ${ }^{31,} 32$ Overall, the different and distinct subcellular localization pattern for each ER subtype may contribute to the diverse actions of estrogen in cardiac cells (Fig. 1).

In addition, GPR30, previously thought to be an orphan membrane receptor, is now recognized as a receptor for E2 involved in E2-mediated rapid, non-genomic signaling, and was re-named G-protein coupled estrogen receptor (GPER). ${ }^{33}$ GPER is present in the heart and shown to be cardioprotective in its function under ischemic and hypertensive stress. ${ }^{34,35}$ In sum, these estrogen receptors are expressed and functional in cardiomyocytes, and orchestrate a myriad of genomic and non-genomic effects in the heart.

\section{ER polymorphism and cardiovascular disease}

Some of the earlier studies involving ERa and ER $\beta$ polymorphism in CVD linked the ER gene variants to the differences in the left ventricular (LV) mass and wall thickness. ${ }^{36,37}$ While the underlying mechanism between the ER polymorphism and phenotypic variation may be complex, it is recognized that ER mutations leading to changes in downstream gene expression and signaling can alter the effects of E2 on the heart. ${ }^{38}$ In fact, single nucleotide polymorphisms (SNPs) in both ERa and ER $\beta$ have been shown to confer susceptibility for CVD. A polymorphism of ERa (minor allele -397T/C) was linked to coronary heart disease among Finnish men. ${ }^{39}$ Another group of ERa variants, ESR1 c.454-397T and ESR1 c. 454-351A, was associated with increased risk of myocardial infarction (MI) and IHD in Dutch women, but not in men. ${ }^{40}$ The rs 1271572 variant of ER $\beta$ was associated with increased risk of MI in men in a Spanish population, ${ }^{41}$ while ER $\beta$ rs 1256049 was linked with reduced risk of CVD or MI in women. ${ }^{42}$ However, the latter study also noted the rs 1271572 variant of ER $\beta$ to be associated with increased risk of MI in women only, in contrast to the previous work showing the variant-specific risk limited to men. ${ }^{41}$ The reasons 
for the reported inconsistency regarding this particular variant are unclear at this time, though differences in methodology and study population are acknowledged.

Thus, while emerging data indicate ERa and ER $\beta$ polymorphism to have a role in genderspecific risk of CVD, further research is needed to determine the underlying mechanisms and the extent of phenotypic expression associated with these genetic variants. Data are currently lacking for GPER polymorphism and cardiac risk, though it has been implicated in cancer risk. ${ }^{43}$

\section{Estrogen and ERs in cardiac metabolism}

Studies consistently indicate that estrogen plays a pivotal role in the control of energy balance and glucose homeostasis via a diverse set of mechanisms. ${ }^{44,} 45$ Postmenopausal women have altered metabolism manifested by increased abdominal adipose tissue and dyslipidemia. ${ }^{46}$ Ovariectomized animals exhibit marked weight gain and dysregulated metabolic state, promptly reversed by E2 replacement. ${ }^{47}$ Data, to date, support ERa at the center of the E2 actions on energy expenditure, as exemplified by ERa knockout (KO) mice which develop adipocyte hyperplasia, insulin resistance, and reduced energy expenditure. ${ }^{48,49}$

Until recently, most of the mechanistic studies examining E2-mediated effects in cellular energy metabolism have been conducted using non-myocardial cells. However, new data are now emerging to detail the role of E2 in the regulation of cardiac metabolism. E2 supplementation significantly improved myocardial ATP levels and mitochondrial respiratory function in the heart. ${ }^{50} \mathrm{ERa}$ and its specific agonist 16a-LE2 were required to maintain physiological glucose uptake in the murine heart. ${ }^{51}$ Cardiomyocyte-specific deletion of ERa changed sex-dependent metabolic gene expression and diverse transcriptional networks in cardiomyocytes. ${ }^{52}$ Interestingly, one study reported regulation of GLUT4 expression by ERa in mouse gastrocnemius muscle, and this may provide an important clue to the underlying molecular mechanisms behind the E2-mediated regulation of glucose metabolism in cardiomyocytes. ${ }^{53}$

Moreover, latest data implicate estrogen related receptor alpha (ERRa) to be a regulator of cellular metabolism via PGC-1a. ${ }^{54}$ Given the high homology of the DNA and ligandbinding domains between ERa and ERRa, and evidence of crosstalk between the two receptors, it is conceivable that ERRa may indirectly enhance E2/ERa signaling or vice versa. ${ }^{55}$ This may serve as yet another mechanism by which E2/ER modulates pathways involved in cardiac bioenergetics.

The role of ER $\beta$ in metabolic regulation is less evident, and available data conflicting. Deleting ER $\beta$ did not affect total body fat or lipoprotein levels of mice, ${ }^{56}$ and the selective ER $\beta$ agonist diarylpropionitrile (DPN) did not alter food intake or body weight gain in rats. ${ }^{57}$ This is in contrast to another study which showed that use of ER $\beta$ ligands alleviated obesity induced by high fat diet and ovariectomy in mice, putatively by repressing several genes involved in the lipogenesis pathways and increasing energy expenditure through uncoupled respiration. ${ }^{58}$ Other studies also support that ER $\beta$ controls cellular metabolism 
through mitochondria. ${ }^{32,} 59$ In an ischemia/reperfusion (I/R) injury model using cardiacspecific ERa and ER $\beta$ KO mice, Gabel et al. showed that the expression of several fatty acid metabolism genes in the heart was differentially altered by ER $\beta$, when compared to ERa or wild-type mice. ${ }^{60} \mathrm{ER} \beta$ was reported to regulate mitochondrial respiratory complex IV activity in rat hearts after trauma-hemorrhage, ${ }^{61}$ with ER $\beta$-specific cardioprotection via upregulation of PGC-1a. ${ }^{62}$

In sum, while there is strong evidence to position E2/ERs as a major regulator of cardiomyocyte metabolism and energy balance, further work is needed to refine and integrate proposed working mechanisms.

\section{Estrogen and ERs in myocardial apoptosis}

The anti-apoptotic effects of estrogen on cardiomyocytes were first reported by Pelzer et al. in $2000 .{ }^{63}$ Since then, several signaling pathways have been attributed to the E2/ERmediated inhibition of myocyte apoptosis. They include inhibition of NF- $\kappa \mathrm{B},{ }^{64}$ activation of phospho-inositide-3 kinase/Akt signaling, ${ }^{65}$ inhibition of ASK1 activity, ${ }^{66}$ upregulating corticotropin-releasing hormone receptor type $2,{ }^{67}$ and more recently, promotion of $\mathrm{p} 38 \beta$ activity leading to inhibition of p53 and subsequent mitigation of mitochondrial redox response. ${ }^{68-70}$ Both Fas- and mitochondria-dependent apoptotic pathways are prevented by E2. ${ }^{71}$ Thus, cumulative data from both in-vitro and in-vivo experiments employing a variety of apoptotic triggers have consistently shown that E2 attenuates cardiac apoptosis.

What is not clear-cut is the extent of contribution by the ER subtypes to this anti-apoptotic action of E2. There are data available to support participation of both ERa and ER $\beta$ in mitigating cell death. Both isoforms are present in cardiomyocytes. ${ }^{23}$ Animal models testing either isoform led to positive results for the studied receptor subtype in offering cardioprotection. ${ }^{72,73}$ One study did make a head-to-head comparison between ERa and ER $\beta$ in this regard by using wild type (WT), ERaKO and ER $\beta K O$ mice in an ex-vivo model of global ischemia/reperfusion. ${ }^{60}$ In the study, ER $\beta K O$ female hearts exhibited significantly less functional recovery than WT, while the extent of I/R injury was similar between $\mathrm{ERaKO}$ and WT female hearts, suggesting that ER $\beta$ plays a larger protective role in the female heart. ${ }^{60}$

Overall, literature to date yields no consensus on which ER receptor has a dominant role in cardioprotection. This may be due to variations in the experimental models, endpoints, and applied doses of ER agonists from one report to another, as well as selection bias. Mechanistic studies using cultured cardiomyocytes have yielded similarly mixed results. ${ }^{74,75}$ To this end, a possibility of ERs working as heterodimers has been considered, as heterodimeric $\mathrm{ER} \alpha / \beta$ was shown to be transcriptionally active in noncardiac cells. ${ }^{76,77}$ Further investigation is needed, however, to confirm the role of ER heterodimer in cardioprotection in vivo.

\section{Estrogen and ERs in cardiac regeneration}

Along with the ability of E2 to protect cardiomyocytes from stress-induced cell death, another novel mechanism may be at hand for the hormone to preserve the integrity of 
cardiac function: stimulation of myocyte regeneration. The latest evidence shows that the infusion of $\mathrm{E} 2$ treated-cardiac stem cells (CSCs) into the isolated mouse hearts leads to a more robust production of CSC-derived protective factors and improved cardiac function as well as better cardiomyocyte survival after acute I/R ${ }^{78} \mathrm{E} 2$ promotes mouse embryonic stem cell proliferation. ${ }^{79}$ Both ERa and ER $\beta$ contribute to E2-mediated endothelial progenitor cell activation and tissue incorporation to the effect of preserving cardiac function after MI. ${ }^{80}$ Of the ER subtypes, ERa may have more profound and direct effects on cardiac progenitor cells in situ, as the receptor was upregulated in post-infarct c-Kit+ precursor cells accumulating in peri-infarct myocardium, and supported proliferation of undifferentiated myoblast cells. ${ }^{81}$ ERa stimulation by E2 and PPT (ERa-specific agonist) reduced apoptosis and increased survival of adult myocytes co-cultured with post-infarct cardiac c-kit+ cells, while ER $\beta$-selective agonist DPN had no effect. ${ }^{81}$

These findings provide an exciting complementary mechanism of how E2 protects cardiomyocytes, and may prove a novel therapeutic strategy in the treatment and management of IHD.

\section{Estrogen and ERs in myocardial hypertrophy}

The involvement of E2/ERs in the LV hypertrophic response ranges from regulating normal physiological responses to exercise and postnatal cardiac growth to mitigating maladaptive ventricular hypertrophy.

As with the anti-apoptotic actions, both ER isoforms are implicated in the anti-hypertrophic effect of E2 against various pathological stimuli. ${ }^{82,83}$ The purported molecular mechanisms involve calcineurin degradation, ${ }^{84}$ mTOR signaling, ${ }^{85}$ regulation of phosphorylated $\mathrm{p} 38$ MAPK pathways. ${ }^{86}$ and regulation of cardiomyocyte histone deacetylases. ${ }^{87}$ Under normal physiological conditions, ER $\beta$ was shown to be responsible for sex differences in exerciseinduced hypertrophy, ${ }^{88}$ while estrogenic regulation for normal myocardial development was primarily via ERa. ${ }^{89}$

One of the more recent developments in the study of cardiac hypertrophy is the identification of endonuclease $\mathrm{G}$ (EndoG) as a central link between maladaptive left ventricular hypertrophy $(\mathrm{LVH})$ and mitochondrial processes. ${ }^{90}$ As of this writing, evidence for a direct relationship between estrogen and EndoG is scant, and none pertaining to their interaction in the heart, though one study showed a correlation between E2 administration and EndoG release in the central nervous system. ${ }^{91}$ Given the strong physiological data on the role of E2 in LVH, probing the relationship between the E2/ER and EndoG may potentially be an exciting area of research to broaden current understanding of estrogenmediated myocardial hypertrophic response.

\section{Estrogen and ERs in cardiac electrophysiology and contraction}

Sex differences in the electrophysiological properties of the heart have long been recognized. There are notable differences between surface electrocardiograms (ECG) of healthy men and women, with women more likely to have a longer QTc interval, faster 
resting heart rate and shorter QRS duration. ${ }^{92,93}$ Though QTc varies within a menstrual cycle, whether the hormonal fluctuation accounts for the change is not yet clear.

Nonetheless, a large body of evidence supports that estrogen directly impacts the electrical conduction properties of cardiomyocytes. In one of the earliest animal models of I/Rinduced ventricular arrhythmia, dogs receiving conjugated equine estrogen had a significantly lower incidence of lethal ventricular tachyarrhythmias. ${ }^{94}$ Subsequent mechanistic studies linked the antiarrhythmic effects of estrogen during I/R to the augmentation of endogenous nitric oxide (NO) release and opening of $\mathrm{K}_{\mathrm{Ca}}$ channels, as well as $\mathrm{Na}^{+} / \mathrm{H}^{+}$exchanger (NHE1) inhibition in the heart. ${ }^{95,96}$

Ovariectomy induces myocardial contractile dysfunction in female rats, ${ }^{97}$ suggesting that estrogen plays an important role in cardiac contraction. Significant gender differences in the parameters of cardiac excitation-contraction (E-C) coupling exist between male and female hearts and cultured myocytes. ${ }^{98}$ The underlying mechanism may be due to the regulation of calcium homeostasis by E2/ER in the heart. E2 inhibits L-type $\mathrm{Ca}^{2+}$ channels, and regulates the membrane density and expression of both L-type $\mathrm{Ca}^{2+}$ channels and low-voltageactivated $\mathrm{Ca}(\mathrm{V}) 3.2$ T-type calcium channels. ${ }^{99-101}$ Interestingly, one study showed that these effects were not mediated by ERa or ER $\beta$, while other reports support the ER involvement in regulating electrophysiological and contractile activities of cardiomyocytes. ${ }^{102-104}$ Together, they suggest E2 actions on cardiac conduction and contraction to be ER subtypeand target channel-specific.

There is currently limited evidence to suggest a role of GPER in cardiac contractility and ion channel activity. ${ }^{105}$ Whether rapid signaling from GPER by E2 modulates cardiomyocyte E$\mathrm{C}$ coupling needs further confirmation.

\section{Conclusion}

Sex differences in cardiovascular diseases have long eluded a satisfactory cohesive explanation. While research is ongoing to narrow this gap of knowledge, there is an abundance of accumulated clinical and experimental evidence to demonstrate the efficacy of E2/ERs in cardioprotection. E2 and its receptors play a critical role in an intricate network of genomic and non-genomic pathways to regulate cardiac metabolism, attenuate cardiomyocyte apoptosis, promote cardiac regeneration, modulate physiological and pathological LVH, and calibrate electrical and contractile function of the heart (Fig. 2). Yet, despite the well-known statistics on the differential outcomes and physiological distinctions between men and women with CVD, no gender-specific treatment strategies exist at this time. The collective body of knowledge from current and future research on estrogen and its role in the heart will be essential to developing much needed therapies that may be both personalized and gender-specific, and advance the field of cardiovascular medicine.

\section{Acknowledgments}

Funding Sources

This work was supported by a grant from the National Heart, Lung, Blood Institute at the National Institutes of Health (R01HL111180 to J.K.K.). 


\section{References}

1. Harman SM. Menopausal hormone treatment cardiovascular disease: Another look at an unresolved conundrum. Fertil Steril. 2014; 101:887-97. [PubMed: 24680648]

2. Rossouw JE, Anderson GL, Prentice RL, et al. Risks and benefits of estrogen plus progestin in healthy postmenopausal women: Principal results from the women's health initiative randomized controlled trial. JAMA. 2002; 288:321-33. [PubMed: 12117397]

3. Grady D, Herrington D, Bittner V, et al. Cardiovascular disease outcomes during 6. 8 years of hormone therapy: Heart and Estrogen/progestin Replacement Study follow-up (HERS II). JAMA. 2002; 288:49-57. [PubMed: 12090862]

4. Gurney EP, Nachtigall MJ, Nachtigall LE, Naftolin F. The women's health initiative trial and related studies: 10 years later: A clinician's view. J Steriod Biochem Mol Biol. 2014; 142:4-11.

5. Harman SM, Black DM, Naftolin F, et al. Arterial imaging outcomes and cardiovascular risk factors in recently menopausal women: A randomized trial. Ann Intern Med. 2014; 161:249-60. [PubMed: 25069991]

6. Hodis HN, Mack WJ, Shoupe D, et al. Methods and baseline cardiovascular data from the early versus late intervention trial with estradiol testing the menopausal hormone timing hypothesis. Menopause. 2015; 22:391-401. [PubMed: 25380275]

7. Manson JE. The 'timing hypothesis' for estrogen therapy in menopausal symptom management. Womens health. 2015; 11:437-40.

8. Chakrabarti S, Morton JS, Davidge ST. Mechanisms of estrogen effects on the endothelium: An overview. Can J Cardiol. 2014; 30:705-12. [PubMed: 24252499]

9. Gilligan DM, Quyyumi AA, Cannon RO 3rd. Effects of physiological levels of estrogen on coronary vasomotor function in postmenopausal women. Circulation. 1994; 89:2545-51. [PubMed: 8205663]

10. Stocco C. Tissue physiology and pathology of aromatase. Steroids. 2012; 77:27-35. [PubMed: 22108547]

11. Weniger JP, Zeis A. aromatization of testosterone by the rat embryo testis. C R Seances Acad Sci III. 1983; 296:293-6. [PubMed: 6405991]

12. Tsugaya M, Harada N, Tozawa K, et al. Aromatase mrna levels in benign prostatic hyperplasia and prostate cancer. Int J Urol. 1996; 3:292-6. [PubMed: 8844286]

13. Trotter A, Maier L, Grill HJ, Wudy SA, Pohlandt F. 17beta-estradiol and progesterone supplementation in extremely low-birth-weight infants. Pediatr Res. 1999; 45:489-93. [PubMed: 10203139]

14. Ling S, Komesaroff P, Sudhir K. Cellular mechanisms underlying the cardiovascular actions of oestrogens. Clin Sci. 2006; 111:107-18. [PubMed: 16831130]

15. Hong Y, Li H, Yuan YC, Chen S. Molecular characterization of aromatase. Ann N Y Acad Sci. 2009; 1155:112-20. [PubMed: 19250198]

16. Harada N, Utsumi T, Takagi Y. Tissue-specific expression of the human aromatase cytochrome p-450 gene by alternative use of multiple exons 1 and promoters, and switching of tissue-specific exons 1 in carcinogenesis. Proc Natl Acad Sci U S A. 1993; 90:11312-6. [PubMed: 8248245]

17. Bell JR, Mellor KM, Wollermann AC, et al. Aromatase deficiency confers paradoxical postischemic cardioprotection. Endocrinology. 2011; 152:4937-47. [PubMed: 22028441]

18. Grohe C, Kahlert S, Lobbert K, Vetter H. Expression of oestrogen receptor alpha and beta in rat heart: Role of local oestrogen synthesis. J Endocrinol. 1998; 156:R1-7. [PubMed: 9518889]

19. Jazbutyte V, Stumpner J, Redel A, et al. Aromatase inhibition attenuates desflurane-induced preconditioning against acute myocardial infarction in male mouse heart in vivo. PloS One. 2012; 7:e42032. [PubMed: 22876297]

20. Balthazart J, Charlier TD, Cornil CA, et al. Sex differences in brain aromatase activity: Genomic and non-genomic controls. Front Endocrinol. 2011; 2:34.

21. Kumar P, Kamat A, Mendelson CR. Estrogen receptor alpha (ERalpha) mediates stimulatory effects of estrogen on aromatase (CYP19) gene expression in human placenta. Mol Endocrinol. 2009; 23:784-93. [PubMed: 19299445] 
22. Beitelshees AL, Johnson JA, Hames ML, et al. Aromatase gene polymorphisms are associated with survival among patients with cardiovascular disease in a sex-specific manner. PloS One. 2010; 5:e15180. [PubMed: 21170323]

23. Grohe C, Kahlert S, Lobbert K, et al. Cardiac myocytes and fibroblasts contain functional estrogen receptors. FEBS Lett. 1997; 416:107-12. [PubMed: 9369244]

24. Mahmoodzadeh S, Eder S, Nordmeyer J, et al. Estrogen receptor alpha up-regulation and redistribution in human heart failure. FASEB J. 2006; 20:926-34. [PubMed: 16675850]

25. Taylor AH, Al-Azzawi F. Immunolocalisation of oestrogen receptor beta in human tissues. J Mol Endocrinol. 2000; 24:145-55. [PubMed: 10657006]

26. Lizotte E, Grandy SA, Tremblay A, Allen BG, Fiset C. Expression, distribution and regulation of sex steroid hormone receptors in mouse heart. Cell Physiol Biochem. 2009; 23:75-86. [PubMed: 19255502]

27. Knowlton AA, Lee AR. Estrogen and the cardiovascular system. Pharmacol Ther. 2012; 135:5470. [PubMed: 22484805]

28. Bowling MR, Xing D, Kapadia A, et al. Estrogen effects on vascular inflammation are age dependent: Role of estrogen receptors. Arterioscler Thromb Vasc Biol. 2014; 34:1477-85. [PubMed: 24876352]

29. Holm A, Nilsson BO. Identification and characterization of new mechanisms in vascular oestrogen signalling. Basic Clin Pharmacol Toxicol. 2013; 113:287-93. [PubMed: 23953673]

30. Barnabas O, Wang H, Gao XM. Role of estrogen in angiogenesis in cardiovascular diseases. J Geriatr Cardiol. 2013; 10:377-82. [PubMed: 24454332]

31. Jazbutyte V, Kehl F, Neyses L, Pelzer T. Estrogen receptor alpha interacts with 17betahydroxysteroid dehydrogenase type 10 in mitochondria. Biochem Biophys Res Commun. 2009; 384:450-4. [PubMed: 19422801]

32. Yang SH, Liu R, Perez EJ, et al. Mitochondrial localization of estrogen receptor beta. Proc Natl Acad Sci U S A. 2004; 101:4130-5. [PubMed: 15024130]

33. Meyer MR, Haas E, Prossnitz ER, Barton M. Non-genomic regulation of vascular cell function and growth by estrogen. Mol Cell Endocrinol. 2009; 308:9-16. [PubMed: 19549587]

34. Deschamps AM, Murphy E. Activation of a novel estrogen receptor, GPER, is cardioprotective in male and female rats. Am J Physiol Heart Circ Physiol. 2009; 297:H1806-13. [PubMed: 19717735]

35. Jessup JA, Lindsey SH, Wang H, Chappell MC, Groban L. Attenuation of salt-induced cardiac remodeling and diastolic dysfunction by the gper agonist $\mathrm{g}-1$ in female mren2. Lewis rats PloS One. 2010; 5:e15433. [PubMed: 21082029]

36. Leibowitz D, Dresner-Pollak R, Dvir S, Rokach A, Reznik L, Pollak A. Association of an estrogen receptor-alpha gene polymorphism with left ventricular mass. Blood Press. 2006; 15:45-50. [PubMed: 16492615]

37. Peter I, Shearman AM, Vasan RS, et al. Association of estrogen receptor beta gene polymorphisms with left ventricular mass and wall thickness in women. Am J Hypertens. 2005; 18:1388-95. [PubMed: 16280269]

38. Barone I, Brusco L, Fuqua SA. Estrogen receptor mutations and changes in downstream gene expression and signaling. Clin Cancer Res. 2010; 16:2702-8. [PubMed: 20427689]

39. Kunnas T, Silander K, Karvanen J, Valkeapaa M, Salomaa V, Nikkari S. Esr1 genetic variants, haplotypes and the risk of coronary heart disease and ischemic stroke in the finnish population: A prospective follow-up study. Atherosclerosis. 2010; 211:200-2. [PubMed: 20153472]

40. Schuit SC, Oei HH, Witteman JC, et al. Estrogen receptor alpha gene polymorphisms and risk of myocardial infarction. JAMA. 2004; 291:2969-77. [PubMed: 15213208]

41. Domingues-Montanari S, Subirana I, Tomas M, Marrugat J, Senti M. Association between esr2 genetic variants and risk of myocardial infarction. Clin Chem. 2008; 54:1183-9. [PubMed: 18487282]

42. Rexrode KM, Ridker PM, Hegener HH, Buring JE, Manson JE, Zee RY. Polymorphisms and haplotypes of the estrogen receptor-beta gene (ESR2) and cardiovascular disease in men and women. Clin Chem. 2007; 53:1749-56. [PubMed: 17702854] 
43. Giess M, Lattrich C, Springwald A, Goerse R, Ortmann O, Treeck O. GPR30 gene polymorphisms are associated with progesterone receptor status and histopathological characteristics of breast cancer patients. J Steriod Biochem Mol Biol. 2010; 118:7-12.

44. Mauvais-Jarvis F, Clegg DJ, Hevener AL. The role of estrogens in control of energy balance and glucose homeostasis. Endocr Rev. 2013; 34:309-38. [PubMed: 23460719]

45. Gupte AA, Pownall HJ, Hamilton DJ. Estrogen: An emerging regulator of insulin action and mitochondrial function. J Diabetes Res. 2015; 2015:916585. [PubMed: 25883987]

46. Carr MC. The emergence of the metabolic syndrome with menopause. J Clin Endocrinol Metab. 2003; 88:2404-11. [PubMed: 12788835]

47. Wallen WJ, Belanger MP, Wittnich C. Sex hormones and the selective estrogen receptor modulator tamoxifen modulate weekly body weights and food intakes in adolescent and adult rats. J Nutr. 2001; 131:2351-7. [PubMed: 11533278]

48. Heine PA, Taylor JA, Iwamoto GA, Lubahn DB, Cooke PS. Increased adipose tissue in male and female estrogen receptor-alpha knockout mice. Proc Natl Acad Sci U S A. 2000; 97:12729-34. [PubMed: 11070086]

49. Ribas V, Nguyen MT, Henstridge DC, et al. Impaired oxidative metabolism and inflammation are associated with insulin resistance in ERalpha-deficient mice. Am J Physiol Endocrinol Metab. 2010; 298:E304-19. [PubMed: 19920214]

50. Chen Y, Zhang Z, Hu F, et al. 17beta-estradiol prevents cardiac diastolic dysfunction by stimulating mitochondrial function: A preclinical study in a mouse model of a human hypertrophic cardiomyopathy mutation. J Steroid Biochem Mol Biol. 2015; 147:92-102. [PubMed: 25541436]

51. Arias-Loza PA, Kreissl MC, Kneitz S, et al. The estrogen receptor-alpha is required and sufficient to maintain physiological glucose uptake in the mouse heart. Hypertension. 2012; 60:1070-7. [PubMed: 22892812]

52. Devanathan S, Whitehead T, Schweitzer GG, et al. An animal model with a cardiomyocyte-specific deletion of estrogen receptor alpha: Functional, metabolic, and differential network analysis. PloS One. 2014; 9:e101900. [PubMed: 25000186]

53. Barros RP, Machado UF, Warner M, Gustafsson JA. Muscle glut4 regulation by estrogen receptors ERbeta and ERalpha. Proc Natl Acad Sci U S A. 2006; 103:1605-8. [PubMed: 16423895]

54. Ramjiawan A, Bagchi RA, Albak L, Czubryt MP. Mechanism of cardiomyocyte PGC-1alpha gene regulation by ERRalpha. Biochem Cell Biol. 2013; 91:148-54. [PubMed: 23668787]

55. Stein RA, McDonnell DP. Estrogen-related receptor alpha as a therapeutic target in cancer. Endocr Relat Cancer. 2006; 13(Suppl 1):S25-32. [PubMed: 17259555]

56. Ohlsson C, Hellberg N, Parini P, et al. Obesity and disturbed lipoprotein profile in estrogen receptor-alpha-deficient male mice. Biochem Biophys Res Commun. 2000; 278:640-5. [PubMed: 11095962]

57. Roesch DM. Effects of selective estrogen receptor agonists on food intake and body weight gain in rats. Physiol Behav. 2006; 87:39-44. [PubMed: 16181647]

58. Yepuru M, Eswaraka J, Kearbey JD, et al. Estrogen receptor-\{beta $\}$-selective ligands alleviate high-fat diet- and ovariectomy-induced obesity in mice. J Biol Chem. 2010; 285:31292-303. [PubMed: 20657011]

59. Simpkins JW, Yang SH, Sarkar SN, Pearce V. Estrogen actions on mitochondria--physiological and pathological implications. Mol Cell Endocrinol. 2008; 290:51-9. [PubMed: 18571833]

60. Gabel SA, Walker VR, London RE, Steenbergen C, Korach KS, Murphy E. Estrogen receptor beta mediates gender differences in ischemia/reperfusion injury. J Mol Cell Cardiol. 2005; 38:289-97. [PubMed: 15698835]

61. Hsieh YC, Yu HP, Suzuki T, et al. Upregulation of mitochondrial respiratory complex IV by estrogen receptor-beta is critical for inhibiting mitochondrial apoptotic signaling and restoring cardiac functions following trauma-hemorrhage. J Mol Cell Cardiol. 2006; 41:511-21. [PubMed: 16859701]

62. Hsieh YC, Choudhry MA, Yu HP, et al. Inhibition of cardiac PGC-1alpha expression abolishes ERbeta agonist-mediated cardioprotection following trauma-hemorrhage. FASEB J. 2006; 20:1109-17. [PubMed: 16770010] 
63. Pelzer T, Schumann M, Neumann M, et al. 17beta-estradiol prevents programmed cell death in cardiac myocytes. Biochem Biophys Res Commun. 2000; 268:192-200. [PubMed: 10652235]

64. Pelzer T, Neumann M, de Jager T, Jazbutyte V, Neyses L. Estrogen effects in the myocardium: Inhibition of NF-kappab DNA binding by estrogen receptor-alpha and -beta. Biochem Biophys Res Commun. 2001; 286:1153-7. [PubMed: 11527420]

65. Patten RD, Pourati I, Aronovitz MJ, et al. 17beta-estradiol reduces cardiomyocyte apoptosis in vivo and in vitro via activation of phospho-inositide-3 kinase/Akt signaling. Circ Res. 2004; 95:692-9. [PubMed: 15345655]

66. Satoh M, Matter CM, Ogita H, et al. Inhibition of apoptosis-regulated signaling kinase-1 and prevention of congestive heart failure by estrogen. Circulation. 2007; 115:3197-204. [PubMed: 17562954]

67. Cong B, Zhu X, Cao B, Xiao J, Wang Z, Ni X. Estrogens protect myocardium against ischemia/ reperfusion insult by up-regulation of CRH receptor type 2 in female rats. Int J Cardiol. 2013; 168:4755-60. [PubMed: 23962778]

68. Liu H, Yanamandala M, Lee TC, Kim JK. Mitochondrial p38beta and manganese superoxide dismutase interaction mediated by estrogen in cardiomyocytes. PloS One. 2014; 9:e85272. [PubMed: 24465521]

69. Liu H, Pedram A, Kim JK. Oestrogen prevents cardiomyocyte apoptosis by suppressing p38alphamediated activation of p53 and by down-regulating p53 inhibition on p38beta. Cardiovasc Res. 2011; 89:119-28. [PubMed: 20724307]

70. Kim JK, Pedram A, Razandi M, Levin ER. Estrogen prevents cardiomyocyte apoptosis through inhibition of reactive oxygen species and differential regulation of p38 kinase isoforms. J Biol Chem. 2006; 281:6760-7. [PubMed: 16407188]

71. Liou CM, Yang AL, Kuo CH, Tin H, Huang CY, Lee SD. Effects of 17beta-estradiol on cardiac apoptosis in ovariectomized rats. Cell Biochem Funct. 2010; 28:521-8. [PubMed: 20803709]

72. Wang M, Crisostomo P, Wairiuko GM, Meldrum DR. Estrogen receptor-alpha mediates acute myocardial protection in females. Am J Physiol Heart Circ Physiol. 2006; 290:H2204-9. [PubMed: 16415070]

73. Wang M, Crisostomo PR, Markel T, Wang Y, Lillemoe KD, Meldrum DR. Estrogen receptor beta mediates acute myocardial protection following ischemia. Surgery. 2008; 144:233-8. [PubMed: 18656630]

74. Liu CJ, Lo JF, Kuo CH, et al. Akt mediates 17beta-estradiol and/or estrogen receptor-alpha inhibition of LPS-induced tumor necresis factor-alpha expression and myocardial cell apoptosis by suppressing the JNK1/2-NFkappaB pathway. J Cell Mol Med. 2009; 13:3655-67. [PubMed: 20196785]

75. Cao J, Zhu T, Lu L, et al. Estrogen induces cardioprotection in male C57BL/6J mice after acute myocardial infarction via decreased activity of matrix metalloproteinase- 9 and increased AktBcl-2 anti-apoptotic signaling. Int J Mol Med. 2011; 28:231-7. [PubMed: 21519786]

76. Li X, Huang J, Yi P, Bambara RA, Hilf R, Muyan M. Single-chain estrogen receptors (ERs) reveal that the ERalpha/beta heterodimer emulates functions of the ERalpha dimer in genomic estrogen signaling pathways. Mol Cell Biol. 2004; 24:7681-94. [PubMed: 15314175]

77. Cowley SM, Hoare S, Mosselman S, Parker MG. Estrogen receptors alpha and beta form heterodimers on DNA. J Biol Chem. 1997; 272:19858-62. [PubMed: 9242648]

78. Wang L, Gu H, Turrentine M, Wang M. Estradiol treatment promotes cardiac stem cell (CSC)derived growth factors, thus improving CSC-mediated cardioprotection after acute ischemia/ reperfusion. Surgery. 2014; 156:243-52. [PubMed: 24957669]

79. Han HJ, Heo JS, Lee YJ. Estradiol-17beta stimulates proliferation of mouse embryonic stem cells: Involvement of MAPKs and CDKs as well as protooncogenes. Am J Physiol Cell Physiol. 2006; 290:C1067-75. [PubMed: 16291822]

80. Hamada H, Kim MK, Iwakura A, et al. Estrogen receptors alpha and beta mediate contribution of bone marrow-derived endothelial progenitor cells to functional recovery after myocardial infarction. Circulation. 2006; 114:2261-70. [PubMed: 17088460] 
81. Brinckmann M, Kaschina E, Altarche-Xifro W, et al. Estrogen receptor alpha supports cardiomyocytes indirectly through post-infarct cardiac c-kit+ cells. J Mol Cell Cardiol. 2009; 47:66-75. [PubMed: 19341743]

82. Pelzer T, Jazbutyte V, Hu K, et al. The estrogen receptor-alpha agonist 16alpha-LE2 inhibits cardiac hypertrophy and improves hemodynamic function in estrogen-deficient spontaneously hypertensive rats. Cardiovasc Res. 2005; 67:604-12. [PubMed: 15950203]

83. Jazbutyte V, Arias-Loza PA, Hu K, et al. Ligand-dependent activation of ER \{beta\} lowers blood pressure and attenuates cardiac hypertrophy in ovariectomized spontaneously hypertensive rats. Cardiovasc Res. 2008; 77:774-81. [PubMed: 18056768]

84. Donaldson C, Eder S, Baker C, et al. Estrogen attenuates left ventricular and cardiomyocyte hypertrophy by an estrogen receptor-dependent pathway that increases calcineurin degradation. Circ Res. 2009; 104:265-75. 11-275. [PubMed: 19074476]

85. Gurgen D, Kusch A, Klewitz R, et al. Sex-specific mTOR signaling determines sexual dimorphism in myocardial adaptation in normotensive DOCA-salt model. Hypertension. 2013; 61:730-6. [PubMed: 23339165]

86. van Eickels M, Grohe C, Cleutjens JP, Janssen BJ, Wellens HJ, Doevendans PA. 17beta-estradiol attenuates the development of pressure-overload hypertrophy. Circulation. 2001; 104:1419-23. [PubMed: 11560859]

87. Pedram A, Razandi M, Narayanan R, Dalton JT, McKinsey TA, Levin ER. Estrogen regulates histone deacetylases to prevent cardiac hypertrophy. Mol Biol Cell. 2013; 24:3805-18. [PubMed: 24152730]

88. Dworatzek E, Mahmoodzadeh S, Schubert C, et al. Sex differences in exercise-induced physiological myocardial hypertrophy are modulated by oestrogen receptor beta. Cardiovasc Res. 2014; 102:418-28. [PubMed: 24654233]

89. Kararigas G, Nguyen BT, Jarry H. Estrogen modulates cardiac growth through an estrogen receptor alpha-dependent mechanism in healthy ovariectomized mice. Mol Cell Endocrinol. 2014; 382:909-14. [PubMed: 24275180]

90. McDermott-Roe C, Ye J, Ahmed R, et al. Endonuclease $\mathrm{g}$ is a novel determinant of cardiac hypertrophy and mitochondrial function. Nature. 2011; 478:114-8. [PubMed: 21979051]

91. Pereira RT, Porto CS, Abdalla FM. Ovariectomy and 17beta-estradiol replacement play a role on the expression of Endonuclease-G and phosphorylated cyclic AMP response element-binding (CREB) protein in hippocampus. Mol Cell Endocrinol. 2014; 382:227-33. [PubMed: 24121025]

92. Nakagawa M, Ooie T, Ou B, et al. Gender differences in autonomic modulation of ventricular repolarization in humans. J Cardiovasc Electrophysiol. 2005; 16:278-84. [PubMed: 15817086]

93. Bernal O, Moro C. cardiac arrhythmias in women. Rev Esp Cardiol. 2006; 59:609-18. [PubMed: 16790203]

94. McHugh NA, Cook SM, Schairer JL, Bidgoli MM, Merrill GF. Ischemia- and reperfusion-induced ventricular arrhythmias in dogs: Effects of estrogen. Am J Physiol. 1995; 268:H2569-73. [PubMed: 7611507]

95. Anderson SE, Kirkland DM, Beyschau A, Cala PM. Acute effects of 17beta-estradiol on myocardial $\mathrm{pH}, \mathrm{Na}+$, and $\mathrm{Ca} 2+$ and ischemia-reperfusion injury. Am J Physiol Cell Physiol. 2005; 288:C57-64. [PubMed: 15385267]

96. Node K, Kitakaze M, Kosaka H, Minamino T, Funaya H, Hori M. Amelioration of ischemia- and reperfusion-induced myocardial injury by 17 beta-estradiol: Role of nitric oxide and calciumactivated potassium channels. Circulation. 1997; 96:1953-63. [PubMed: 9323086]

97. Ribeiro RF Jr, Pavan BM, Potratz FF, et al. Myocardial contractile dysfunction induced by ovariectomy requires at1 receptor activation in female rats. Cell Physiol Biochem. 2012; 30:1-12. [PubMed: 22759951]

98. Parks RJ, Howlett SE. Sex differences in mechanisms of cardiac excitation-contraction coupling. Pflugers Arch. 2013; 465:747-63. [PubMed: 23417603]

99. Johnson BD, Zheng W, Korach KS, Scheuer T, Catterall WA, Rubanyi GM. Increased expression of the cardiac L-type calcium channel in estrogen receptor-deficient mice. J Gen Physiol. 1997; 110:135-40. [PubMed: 9236206] 
100. Marni F, Wang Y, Morishima M, Shimaoka T, Uchino T, Zheng M, Kaku T, Ono K. 17 betaestradiol modulates expression of low-voltage-activated $\mathrm{Ca}(\mathrm{v}) 3$. 2 T-type calcium channel via extracellularly regulated kinase pathway in cardiomyocytes. Endocrinology. 2009; 150:879-88. [PubMed: 18832095]

101. Nakajima T, Iwasawa K, Oonuma H, Morita T, Goto A, Wang Y, Hazama H. Antiarrhythmic effect and its underlying ionic mechanism of 17beta-estradiol in cardiac myocytes. British journal of pharmacology. 1999; 127:429-440. [PubMed: 10385243]

102. El Gebeily G, El Khoury N, Mathieu S, Brouillette J, Fiset C. Estrogen regulation of the transient outward $\mathrm{k}(+)$ current involves estrogen receptor alpha in mouse heart. J Mol Cell Cardiol. 2015; 86:85-94. [PubMed: 26205295]

103. Kulpa J, Chinnappareddy N, Pyle WG. Rapid changes in cardiac myofilament function following the acute activation of estrogen receptor-alpha. PloS One. 2012; 7:e41076. [PubMed: 22859967]

104. Ullrich ND, Krust A, Collins P, MacLeod KT. Genomic deletion of estrogen receptors ERalpha and ERbeta does not alter estrogen-mediated inhibition of $\mathrm{Ca} 2+$ influx and contraction in murine cardiomyocytes. Am J Physiol Heart Circ Physiol. 2008; 294:H2421-7. [PubMed: 18441199]

105. Gao Q, Liu S, Guo F, et al. Nonylphenol affects myocardial contractility and L-type Ca(2+) channel currents in a non-monotonic manner via $G$ protein-coupled receptor 30. Toxicology. 2015; 334:122-9. [PubMed: 26070386] 


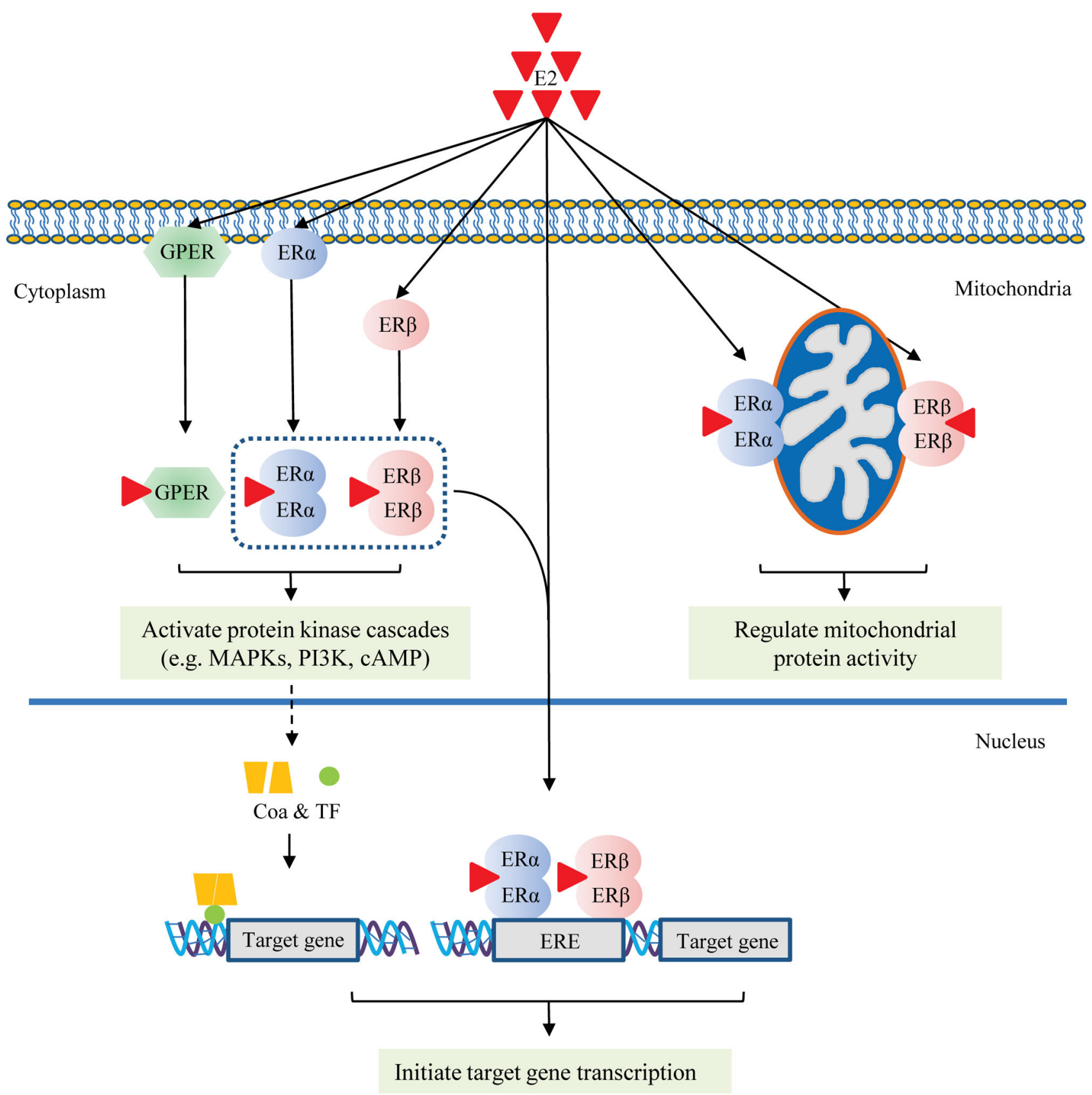

Fig. 1. Model of estrogen (E2) action via estrogen receptors (ERs) in the cardiomyocyte Genomic pathway (1): E2 directly activates ERa and ER $\beta$, which bind to the estrogenresponse-element (ERE) of gene promoters and induce target gene transcription. Rapid or non-genomic pathway (2): E2 activates ERs (GPER, ERa and ER $\beta$ ) in the membrane and cytoplasm, leading to rapid changes in signaling pathways involving protein kinase cascades, which in turn affect downstream gene transcription via co-activators $(\mathrm{CoA})$ and transcription factors (TF). In addition, E2 also activates ERs (ERa and ER $\beta$ ) located in mitochondria and regulates mitochondrial function and energy homeostasis. 


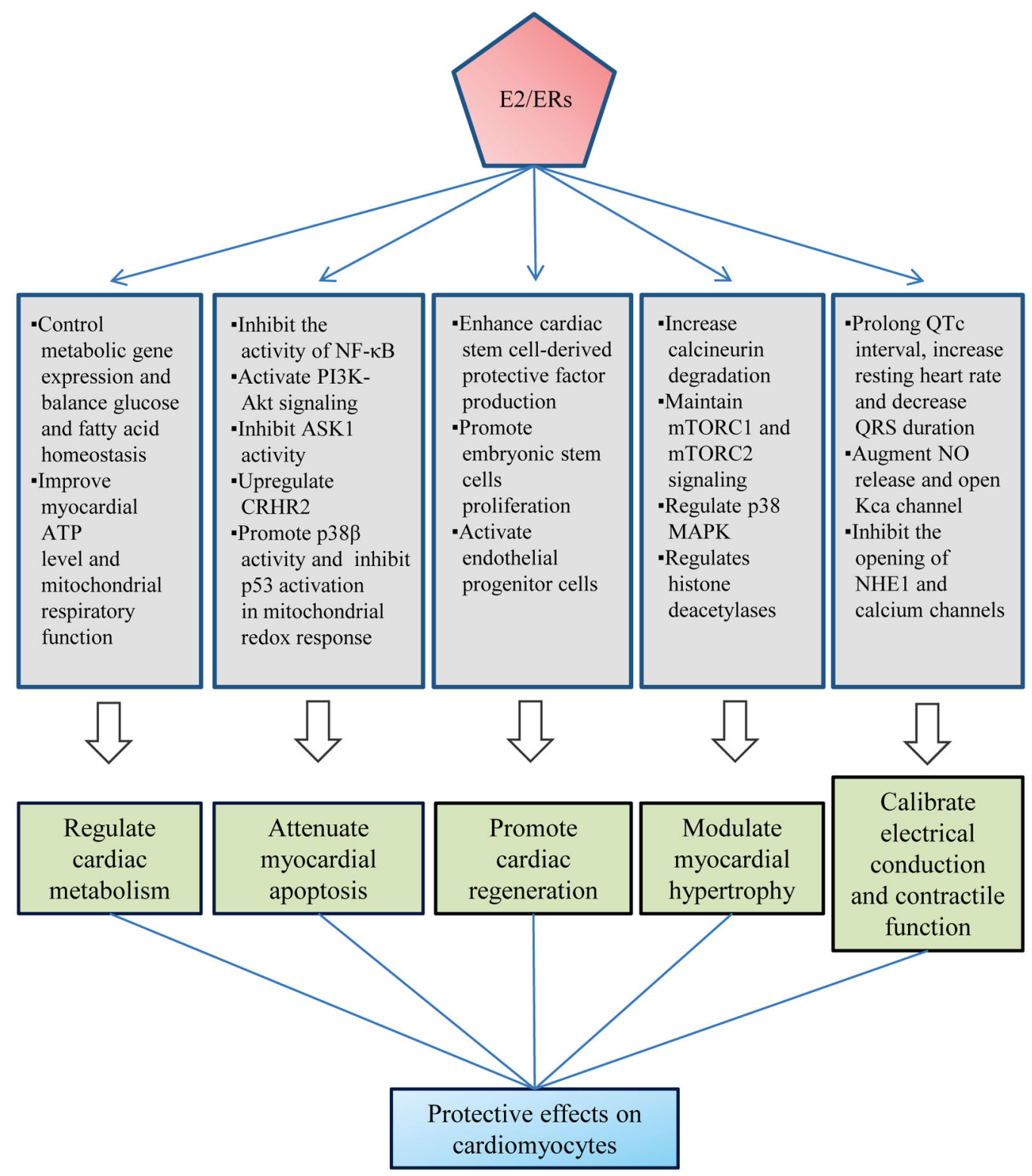

Fig. 2.

Summary of key effects of E2/ER on cardiomyocytes. 